\section{Research Article}

(C) 2021 Ismail et al.. This is an open access article licensed under the Creative Commons Attribution-NonCommercial 4.o International License (https://creativecommons.org/licenses/by-nc/4.o/)

\title{
An Appraisal of Digital Documents as Evidence in Islamic Law
}

\author{
Wan Abdul Fattah Wan Ismail* \\ Ahmad Syukran Baharuddin \\ Lukman Abdul Mutalib \\ Mohamad Aniq Aiman Alias \\ Faculty of Syariah and Law, \\ Universiti Sains Islam Malaysia, \\ Bandar Baru Nilai, 7180o, Nilai, \\ Negeri Sembilan, Malaysia \\ *Corresponding Author
}

DOI: https://doi.org/10.36941/ajis-2021-0o76

\begin{abstract}
Major shifts in the science and technology landscape have made the collection and analysis of digital evidence an increasingly important tool for resolving of crimes as well as the preparation of court cases. Digital documents are known as electronic documents and it can be used as a means of proof in court. However, this kind of method is still need to be discussed in detail regarding its admissibility in the Syariah court. This is because there is no specific provision on the use of it. Thus, this article focuses on the concept of digital documents as evidence in Syariah courts. It also explores the Islamic legal perspective on digital documents as a means of proof by considering the Quran, hadiths, legal maxims, and acts. This article also will focus on the admissibility of digital documents as evidence in Syariah courts. The methodology of this study is a qualitative approach. The data collected is divided into two types: primary sources, such as the Quran, hadiths, legal maxims, and acts; and secondary sources, such as journal articles, books, cases reported in law journals, and kitab fiqh. The data obtained is analyzed using document analysis methods. The results show that there is a high need to accept digital documents as evidence, especially in Syariah courts. This is because, the scientific and technological developments have led to this need to make use of digital documents. Studies show that the use of digital documents as evidence serves to reinforce other evidence presented in court.
\end{abstract}

Keywords: digital document, electronic documents, admissibility, evidence, Syariah court

\section{Introduction}

This rapid growth of science and technology, combined with increasingly sophisticated and nuanced criminal behaviour has made al-Qarinah ever more important (Lukman et al., 2020). The use of the digital document is one of the new methods of al-Qarinah that can be regarded as evidence in a trial. This kind of method has been accepted in civil courts since the 1950 and it remains widely used to the present day (Zuha \& Ramalinggam, 2017). Based on research conducted by Mohamad Ismail (2006), he 
explained the importance of using digital documents in the current situation as evidence because it can reinforce the other evidence.

Generally, the digital document is still relatively new in Syariah courts compared to other forms of proof. Its acceptance as a means of proof is still debated among scholars such as Hanafi, Maliki and part of Syafi and Hanbali (Wan Abdul Fattah, 2020). However, according to Ibnu Taimiyyah (1995) and Ibnu Qayyim (n.d.), anything that can explain and reveal the truth is called as evidence. The challenge to use this kind of method as evidence arises due to the issues of reliability, applicability and authenticity. Another question arises as to whether or not the digital document is accepted in Syariah Islamic law and how it works in trial proceedings. This is because according to Augustine (2010), if the authenticity and admissibility have not been acknowledged by the courts or by the lawyers in document digital so that it cannot be accepted as evidence.

This is important to conduct a study regarding the admissibility of a digital document in Syariah court on what is the view from the Islamic perspective on the use of digital document as a method of proof and how far the Syariah court in Malaysia admit the digital document. This study is expected to be a reference to Syariah practitioners to conduct cases related to the used of digital document in a trial. Thus, this study will focus and explore the admissibility of the digital document as a means of proof in the Syariah court in Malaysia.

\section{Literature Review}

There are a few studies related to this topic. However, there is no proper research which discusses the admissibility of a digital document under Islamic Syariah law in terms of the concept of a digital document from an Islamic point of view and its admissibility in the Syariah court in Malaysia. Instead, the previous literature only focus on the general definition of the digital document, its function and the types of a digital document that can be used as evidence in court.

According to Arthur Gingrande (2010), the author has defined a digital document as a compilation of coded document descriptors, which exist as magnetic impulses on a hard disc and can be considered as legal evidence when viewed with the proper document creator software. On the other hand, digital documents may also be classified as notes or documents which have been produced, stored or extracted, copied or replicated, or transmitted electronically through other electronic equipment and can be clearly understood and interpreted (Muhammad Fawwaz, 2008). From these mentioned-above, the authors only discuss the definition of digital documents and the concept of a digital document in general. The authors do not mention the admissibility of a digital document in court according to Islamic law.

Besides, according to Wan Abdul Fattah (2016), the author highlighted that digital documents such as Closed-circuit television (CCTV), short message service (SMS) and the like are also one of the relatively new methods of proofing compared to others, especially in the Syariah court. This is because, the digital document can provide clear and detailed information, and it is difficult to destroy and easy to handle (Wan Abdul Fattah et al., 2020). However, these two articles did not mention specifically the concept of the digital document as evidence and its admissibility in the Syariah court in Malaysia. Instead, from these studies, the authors only mention generally about the digital document as one of the new methods of proof in the Syariah court and its feature as a mean of proof.

The article entitled "Cases of Electronic Evidence in Malaysian Courts: The civil and Syariah Perspective" by Duryana Mohamed \& Zulfakar Ramlee (2014), states that electronic evidence may be accepted by the Syariah Court because the digital document can also be defined as al-kitabah (one method of proof according to Islamic law). Not only that, the digital document may come under qarinah or circumstantial evidence (Ahmad Syukran, 2017). However, from these two studies, the authors have only discussed the general classification of digital documents as such digital documents also may define as al-kitabah (writing) and also included as qarinah. However, there is no specific discussion in regards to its admissibility under the Syariah court.

In the article Jurnal Undang-undang dan Masyarakat by Zulfakar Ramlee \& Wan Abdul Fattah 
(2013) entitled "Evidence Through Kitabah: According to Fiqh and Current Malaysian Laws", state that the digital document is classified as one form of al-kitabah. This is because, the definition of al-kitabah should be seen in a wider scope as advancements in science and technology have provided many kinds of new document formats, including digital documents. However, this article only mentions generally on the concept of a digital document as one form of al-kitabah. Instead, the author does not discuss its admissibility as a means of proof in the Syariah court.

The study of Mohamad Ismail (2013) found that, the court has authorized the use of email, short message service (SMS), digital photographs, automated teller machine transactions (ATM), internet usage networks, digital video and related to this as acceptable evidence. In the study of Lukman Mutalib \& Wan Abdul Fattah (2012), the authors also suggested several types of modern qarinah such as fingerprints, Deoxyribonucleic Acid (DNA) tests, blood tests, voiceprints, image prints and face prints as a mean of proof in the Syariah court. However, there is no discussion in these studies regarding to the cases reported or the admissibility of a digital document in the Malaysian Syariah court. Instead, these study only suggests and list several types of method of proof that may be accepted in a trial as mentioned above.

The above studies show that, very few studies have been done to study the concept of digital documents according to Islamic legal perspectives and its admissibility in the Malaysia Syariah court. This article indirectly will explore the concept of a digital document as evidence in a trial proceeding. Besides, this article will identify the Islamic legal perspectives on a digital document as a means of proof. Lastly, this article aims to explore the admissibility of the digital document as evidence in the Malaysian Syariah court.

\section{Methodology}

According to Ahmad Syukran (2017), methodology plays an important role in achieving the objectives of a study. This study uses a qualitative methodology, since this research is based in the fields of social sciences and law. Socio-legal methods will be used in qualitative studies by linking social sciences and law with reference to social science journals and provisions in the law in Malaysia (Alias \& Abdul Ghafur, 2017; Suzana \& Zuha, 2018). Qualitative research is primarily exploratory. It is used to gain a better understanding of the underlying reasons, opinions and motivations. It provides insight into the problem or helps to develop ideas or assumptions for potential quantitative research. It is also used to uncover patterns in thinking and opinion and to delve deeper into the issue.

In this article, the collected data is divided into two types: primary and secondary data. In this study, the primary data included the provision from the Quran, the hadiths of the Prophet (SAW), Islamic legal maxims (qawaid fiqhiyyah), and the Syariah Court Evidence (Federal Territories) Act 1997 [Act 561]. These data sources were also used to find out directly about the status of digital documents as a method of proof. This is because the data collected from primary sources are clear, reliable sources, and their interpretation should not be swayed by one's views. Journal articles, books, cases reported in law journals, and kitab fiqh are classified as secondary data. Then, the data obtained were analyzed using document analysis methods and come out with the findings about digital documents as evidence in Islamic Syariah law.

\section{Findings and Discussion}

\subsection{The Concept of Digital Documents as Evidence}

Information technology has contributed to the paradigm shift of the production, processing, exchange, and storing of data information by individuals and organizations. Data and information are stored electronically and can be used as valuable proof that can stored or transmitted in digital form in a trial (Pollitt, 2006). Records are held electronically in digital format. Therefore, the question arises whether such digital evidence is legally acceptable under Malaysian law. In short, the civil courts legally 
recognize such evidence, but its acceptability in Syariah courts is still debated.

Under Section 3 of the Evidence Act 1950 [Act 56], "document" refers to: any matter expressed, described or howsoever represented, upon any substance, material, thing or article, including any matter embodied in a disc, tape, film, soundtrack or other devices whatsoever. The question is whether a digital document can be classified as a document under Section 3 of the Evidence Act 1950 [Act 56]? Based on figure 1, it can be argued that the definition of document under section 3 also refers to the digital document as a form of document. The concept of the document as evidence in Section 3 of the Syariah Court Evidence (Federal Territories) Act 1997 [Act 561] was taken from this act, which has long been practiced in the civil court.

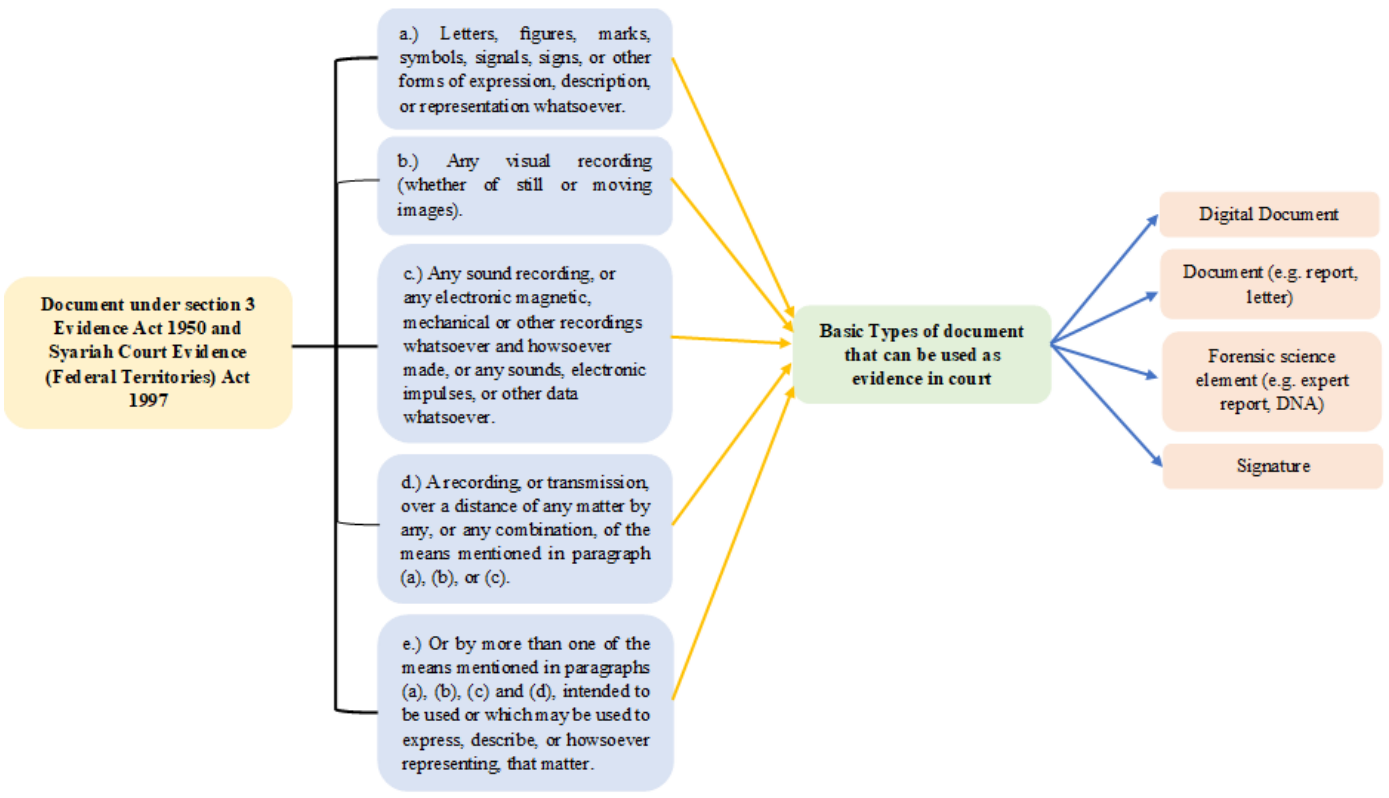

Figure 1: The Concept of Document

Source: Section 3 of the Evidence Act 1950 [Act 56] and the Syariah Court Evidence (Federal Territories) Act 1997 [Act 561]

From this section, it indicates that the document is not limited to the use of certain equipment only, but it is important that the document is readable and physical in nature, whether it can be understood by reading it directly or by using special equipment. Sound recordings, cassettes, compact discs, CDs and others can be included or categorized as document since its content can be understood even with the use of certain equipment to read it (al-Humaidhi, 1989).

According to Ismail (2006), the digital document can be defined as a form of probative information stored, recorded or channeled in electronic form and the material can be presented in court as evidence supporting or denying the allegations. Figure 2 show the sources of electronic and digital evidence that can be used as a method of proof. 


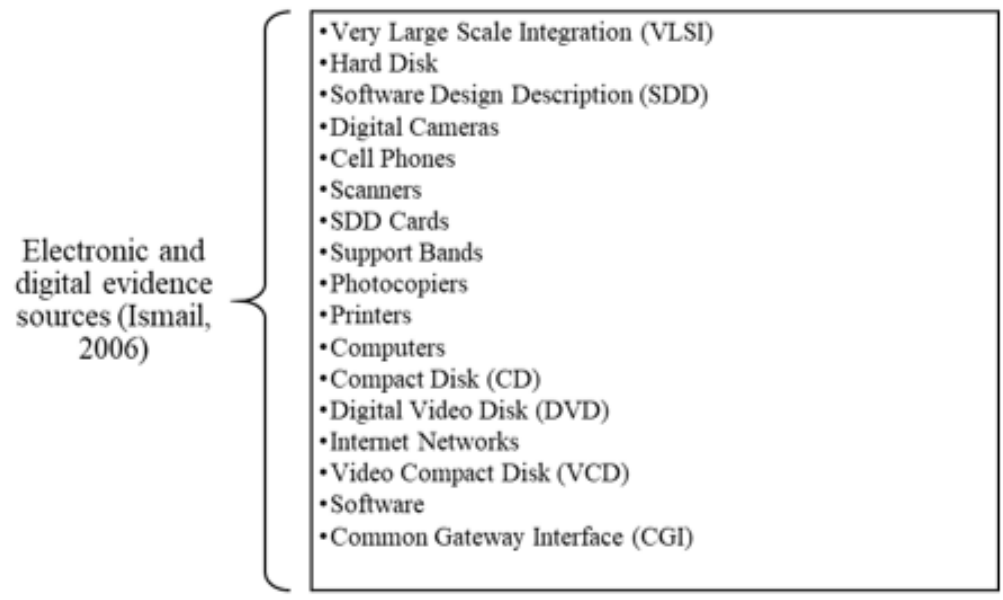

Figure 2: The sources of electronic and digital evidence

Source: Mohamad Ismail, 2006

The used of digital document as a mean of proof has been submitted to reinforce other evidence filed in court. The evidence also needs to be strengthened by expert testimony to test the credibility of the document descriptions (Jasri Jamal, 2011). In Syariah courts, digital documents can be submitted in mal cases to support a divorce case, a marriage declaration, and cases related to nafkah. These electronic and digital evidence are used in prosecution of Syariah crime cases to reinforce the allegations against the accused, for instance, in the accusation of illegal intercourse and khalwat.

Although the details of the Syariah principles relating to such digital documents are not clear, they should be considered an important form of evidence because the description from a digital document can help the court to understand the facts and the evidence.

\subsection{The Islamic Legal Perspective on Digital Documents as a Means of Proof}

Scientific proof through the application of forensic science methods is allowed in Islam (Hazim et al., 2019). Generally, support for the use of digital documents as a means of proof cannot be found clearly in the holy Quran or the hadiths. However, the acceptance of digital documents refers to a general acceptance of the means of proof (Wan Fattah et al., 2018). In relation to hukm or the Islamic legal perspective, there are several sources, such as the Quran, the hadiths, and legal maxims (qawaid fiqhiyyah).

The principles of Syariah illustrate the importance of recording or documenting transactions to avoid any kind of problems, as mentioned in surah al-Baqarah verse 282 :

"Believers! Whenever you contract a debt from one another for a known term, commit it to writing".

(Quran, Al-Baqarah 2:282)

In this verse, Allah Almighty emphasizes the importance of making a written text. This is because it is possible to present a written document as evidence in a court proceeding. From the hadith of the Prophet SAW, he said:

"It is the duty of a Muslim who has something which is to be given as a bequest not to have it for two nights without having his will written down regarding it". (Hadith, Sahih Muslim 13:3987)

It is clear from this hadith that the Messenger of Allah (may peace be upon him) advised us to 
write a will. This is because, if such writing were unimportant and lacking in benefits, the prophet would not have his ummah do it. The legal maxims (qawaid fiqhiyyah) state that "al-kitabah kalkhitab" which means that kitabah is equal to a document. This method indirectly means that each text or document is as acceptable as a conversation.

According to Sections 3, 5-16 of the Syariah Courts Evidence (Federal Territories) Act 1997 [Act 561] and other sections of the Syariah Courts Evidence Enactments, the judge will rely on the evidence and test whether the evidence is strong or weak. If there is any doubt, the evidence should be authenticated by an expert in digital forensics by referring section 33 of the Syariah Courts Evidence (Federal Territories) Act 1997 [Act 561].

Al-ra'yu al-khabir is the testimony of a skilled person in a specific field or is the opinion, proof, or testimony of an individual skilled in a particular area or subject (Bahansi, 1962). Allah SWT asks to seek experts in any case where the people are unable to answer any problems, as mentioned in surah AnNahl, verse 43:

\section{"And We sent not before you except men to whom We revealed [Our message]. So ask the people of the} message if you do not know". (Quran, Yusuf 16:43)

The court will, therefore, seek the opinion of those who are competent in the chosen field, as set out in Section 33 of the Syariah Courts Evidence (Federal Territories) Act 1997 [Act 561] and other Syariah Court Evidence Enactments. The expert opinion is based on a high standard of professional expertise (Wan Abdul Fattah, 2016).

Muslim jurists have also agreed that such digital documents can be used to prove all civil cases, such as those relating to property rather than to matters involving hudud and qisas (Arbouna, 1999). In short, the issue of admissibility is not disputed, but there are disputes over the proof of authenticity of documents produced either by conventional means or by electronic means (Al-Zuhaili, 2004). These arguments indirectly show that digital documents are a method of proof in Islamic Syariah law, because such documents can assist the court to consider the facts and evidence.

\subsection{The Admissibility of Digital Documents as Evidence in the Malaysian Syariah Courts}

In general, the proof is an essential element of a trial proceeding and needs to be presented systematically in court (Suhaizad et al., 2019). To seek justice in a trial, all facts and issues raised must be supported by systematic evidence and presented to the court. Islam sets out the methods of proof, which must be followed in a detailed way. It is unfortunately legal practitioners in the Syariah courts are rarely exposed to cases that involve digital documents (Wan Fattah et al., 2018). Within the Syariah legal framework in Malaysia, knowledge relating to forensic science is considered foreign when applied in the Syariah court (Ahmad Syukran, 2017).

Exceptions to using this means of proof will complicate the process of proving a case. Although the Syariah principles of digital documentary description provide no clear details on the definition and the admissibility of digital documents, it is a form of description that plays an important role in the process of proving cases of mal and Syariah crimes. This is because such documents help to reinforce facts and evidence. The evidence of the digital document supports other existing facts and evidence, so it will help to convince the Syariah court, in particular to accept facts and evidence, and it assists the court in making its decision.

Section 3 of the Syariah Courts (Federal Territories) Evidence Act 1997 sets out that digital documents can be classified as documents. The definition of a document based on Section 3 is further strengthened by the provisions of section 49 of the Syariah Court Evidence (Federal Territories) 1997 [Act 561] which considers computers as primary information that is, a document issued by a computer falls into this category (Wan Abdul Fattah, 2020).

Based on the findings of this study, the researcher found that the Syariah principles recognize the document as a means of proof in Syariah courts. This is because the description helps to support the 
other facts presented in court. For example, in the case of Azida Fazlina v. Shamsudin Latif, the court upheld and convicted the divorced spouse through an SMS when the husband sent an SMS text for a divorce. It indicates that digital information, such as an SMS filed in a Syariah court, helps to confirm that a divorce has taken place between a husband and wife.

In the case of Ahmad Faozi bin Mansor v. Norhafizah binti Ahmad, the defendant had cheated and had sex with another man. In this case, the plaintiff provided evidence of the defendant's cheating by attaching a telephone bill indicating that the defendant always contacted other men. The Syariah court accepted nusyuz's claim based on the evidence of behavior presented in document descriptions such as phone bills and SMS. This shows that document descriptions such as phone bills and SMS are considered to be a digital form of evidence and are used in Syariah courts.

According to section 33 of the Syariah Court Evidence (Federal Territories) 1997 [Act 561], the digital evidence should also be supported by other evidence, such as expert testimony. Such testimony is meant to verify the authenticity of the digital document. In the case of Ajmawati's divorce claim in Ajmawati binti Atan v. Moriazi bin Mohamad, the understanding of the admissibility of the digital description was unclear, which resulted in the case being ordered to be heard again with the submission of the supporting witnesses. The evidence is also admissible in court once it has been supported by expert testimony to test the credibility of the documents (Azhan Yahya et al., 2017).

Studies show that the Syariah Courts recognized the used of digital document as a method of proof by referring to Syariah Islamic law. The several cases listed regarding to the used of digital document as evidence indirectly show that the Syariah practitioners start to use the digital document in the trial. However, the discussion in the context of the implementation of the standard operating procedure (SOP) needs to discuss in detail to be apply in Syariah court.

\section{Conclusion}

The use of a digital document as evidence is permitted in Islamic Syariah law. The concept of using a digital document as evidence is intended to support or refute a legal claim. Sections 3 and 49 of the Syariah Court Evidence (Federal Territories) Act 1997 [Act 561] provide for electronic documents being accepted as evidence. Although there is no clear position on the acceptability of digital documents as evidence in Syariah courts, many studies have considered the use of digital documents as evidence in Syariah courts. The results show that there is a very high need to accept digital documents as evidence, especially in Syariah courts. This need has resulted from scientific and technological developments. Studies show that the use of digital documents as evidence serves to reinforce the other evidence presented in court. Accordingly, the evidence provided by a digital document is admissible in a Syariah court after it has been strengthened by an expert in digital forensics (Al-Ra'yu al-Khabir) to test its credibility. However, the discussion on the use of digital documents as evidence needs to be further extended in the context of the implementation of the standard operating procedure (SOP) in Syariah courts.

\section{Acknowledgements}

We would like to acknowledge the Ministry of Education (MoE), Malaysia through the Fundamental Research Grant Scheme (FRGS) entitled "Pembinaan Model iDoc-Forensics (Kombinasi Al-Qarinah dengan Forensik Dokumen Digital) ke Arah Penyelesaian Kes-Kes Kehakiman di Mahkamah Syariah Malaysia", (FRGS/1/2019/SSIo3/USIM/o2/6), (USIM/FRGS/FSU/055002/50319).

\section{References}

Ahmad Faozi bin Mansor v. Norhafizah binti Ahmad. [2004].

Ajmawati binti Atan v. Moriazi bin Mohamad. [2009].

Al-Humaidi., \& Ibrahim, A. A. (1989). Al-Qada' wa Nizamuhu fi al-Kitab wa al-Sunah. Makkah: Maahad al-Buhuth al-'Ilmiyyah. 
Alias, A., \& Abdul Ghafur, A. H. (2017). DNA Sebagai Qarinah Di Mahkamah Syariah: Analisis Terhadap Enakmen Keterangan Mahkamah Syariah Perlis 2006. International Journal of Law Government and Communication, 2(6), 76-86.

Al-Zuhaylī, W. M. (2004). al-Fiqhu al-Islami Wa Adillatuh. (Vol. 7). Damsyik: Darul Fikr.

Arbouna, M. B. (1999). Islamic Law of Evidence: The Function of Official Documents. Syarikat Nurulhas, Kuala Lumpur, 92-97.

Azida Fazlina v. Shamsudin Latif. [2009].

Bahansi, A. F. (1962). Nazariah al-Ithbat. Kaherah, Mesir: al-Arabiah li al-Tibaa'ah.

Baharuddin, A. S. (2017). Di sebalik Fiqah Forensik. Telaga Biru.

Baharuddin, A. S. (2017). The Integration of Forensic Science Fundamentals and Al-Qarinah Towards Achieving Maqasid Al-Shari'ah. Doctoral dissertation, Universiti Teknologi Malaysia, Skudai.

Craiger, P. (2006). Computer Forensics Methods and Procedures. In H. Bigdoli (Ed.), Handbook of Information Security. (Vol. 2). New York: John Wiley \& Sons, pp. 715-749.

Fawwaz, M. (2008). Al-Wajiz fi al-Uqud al-Tijarah al-Elektroniyyah. 'Amman: Dar alThaqafah.

Gingrande, A. (2010). Digital Documents and the Best Evidence Rule. Document Strategy. [Online] Available: https://documentmedia.com/article-18o-Digital-Documents-and-the-Best-Evidence-Rule.html

Hazim, M., Zakaria, A., Noraishah. \& Baharuddin, A. S. (2019). Analisis Perundangan bagi Undang-undang Keterangan Mahkamah Syariah berkaitan Bukti Saintifik dan Penerimaannya di Mahkamah Syariah. Diskusi Syariah dan Undang-undang, Siri 12019.

Ibnu al-Qayyim (n.d.). Turuq al-Hukmiyyah. Kaherah: Darul Hadis.

Ibnu Taimiyyah. (1995). Majmu' al-Fatawa'. Medina: Majmu al-Malik Fahad Litiba'ah al.

Ismail, M. (2006). Kedudukan Bahan Bukti (Exhibit) Elektronik dan Digital dalam keterangan: Masalah dan Cabaran Masa Kini. The Journal of the Malaysian Bar, 35(1), 1-14.

Jamal, J. (2011). Kebolehterimaan Teknologi dalam Undang-undang Keterangan Islam di Mahkamah Syariah. Jurnal Hukum, 33(1), 1-12.

Mohamed, D. \& Ramlee, Z. (2014). Cases of Electronic Evidence in Malaysian Courts: The civil and Syariah Perspective. ICSSR e-Journal of Social Science Research, 1(2), 1-10.

Mutalib, L. A., \& Wan Ismail, W. A. F. (2012). Al-Qarinah: Antara Kekuatan dan Keperluan dalam Mensabitkan Kesalahan Jenayah (Zina). International Journal of Islamic Thought, 2, 38-54.

Mutalib, L. A., Ismail, W. A. F. W., Baharuddin, A. S., Mohamed, M. F., Murad, A. H. A., Wafa, K. A. M., \& Suhid, A. (2020). Al-Qarinah (Circumstantial Evidence) and Its Capacity in Criminal Cases, Munakahat and Wealth Convictions According to Islam. International Journal of Advanced Science and Technology, 29(3), $1016-1026$. [Online] Available www.scopus.com

Paul, S. A. (2010). Evidence: Practice and Procedure, 4th Edition. LexisNexis.

Ramlee, Z., \& Wan Ismail, W. A. F. (2013). Keterangan Melalui Kitabah: Menurut Fiqh dan Undang-Undang Semasa di Malaysia. Jurnal Undang-undang dan Masyarakat, 17, 1-12.

Said, S. M., \& Zuha, R. M. (2018). Exploring The Legal Aspects and Court Process of Forensics Entomology from The Malaysia's Perspective. Serangga, 23(2), 268-278.

Saifuddin, S., Markom, R., \& Muhamad, M. M. (2019). Kaedah Pembuktian dalam Undang-undang Keterangan Mahkamah Syariah dan Mahkamah Sivil di Malaysia: Suatu Perbandingan. Jurnal Kanun, 31(1), 1-34.

Wan Ismail, W. A. F. (2016). Penerimaan dan Kekuatan Dokumen Elektronik dalam Pembuktian di Mahkamah Syariah di Malaysia. Jurnal Kanun, 28 (2), 338-355.

Wan Ismail, W. A. F. (2020). Keterangan Dokumentar Menurut Fiqh dan Undang-undang Keterangan Islam di Malaysia. Dewan Bahasa dan Pustaka.

Wan Ismail, W. A. F., Abdul Shukor, S., \& Hashim, H., \& Baharuddin, A. S. (2018). Pembuktian Melalui Televisyen/Kamera Litar Tertutup (CCTV) Dalam Kes-kes Jenayah: Tinjauan Umum Berdasarkan Undangundang Keterangan Islam. Malaysian Journal of Syariah and Law (MJSL), 474 (6194), 1-18. [Online] Available https://doi.org/10.12816/0051393

Wan Ismail, W. A. F., Baharuddin, A. S., Mutalib, L., \& Alias, M. A. A. (2020). The Admissibility of Digital Document According to Syariah Law: A Preliminary Analysis. International on Syariah and Law (INSLA), 3(1), 471-480.

Yahya, M. A., Shaariff, A. A. M., \& Abdullah, M. A. H. (2017). Keterangan Dokumen dalam Bentuk Digital di Mahkamah Syariah: Analisis Berkaitan Definisi serta Kebolehterimaannya di Sisi Prinsip Syariah di Malaysia. Current Legal Issues, 1, 1-12.

Yunus, M. I. (2013). Nilai Keterangan Elektronik dan Digital Menurut Akta Keterangan 1950. Pengamam, Official Magazine of Royal Malaysia Police.

Zuha, R. M., \& Rajamanickam, R. (2017). Entomologi Forensik sebagai Keterangan Saintifik. The Law Review, 1, 36-45. 